\title{
Paisagem e lugares: considerações sobre a arte rupestre do Sítio Sampaio, Felício dos Santos, Alto Araçuaí, Minas Gerais: uma análise interpretativa
}

\author{
Landscape and places: considerations on the rock art of the Sampaio Archaeological Site, \\ Felício dos Santos, Alto Araçuaí, Minas Gerais: an interpretative analysis
}

Marcelo Fagundes

Mestre e Doutor em Arqueologia pela Universidade de São Paulo

Docente do curso de Geografia da UFVJM, Brasil marcelofagundes.arqueologia@gmail.com

\author{
Arkley Marques Bandeira \\ Doutor em Arqueologia pela Universidade de São Paulo \\ Docente do curso de Ciências Humanas da UFM (Campus Pinheiro), Brasil \\ arkleybandeira@hotmail.com
}

Wellington Santos Greco Mestrando do Mestrado Profissional Interdisciplinar em Ciências Humanas da UFVJM, Brasil grecow@yahoo.com.br

\section{Resumo}

$\mathrm{O}$ estudo em arte rupestre tem tomado diferentes perspectivas em Arqueologia, dentro os quais suas relações com a paisagem. Neste caminho, o objetivo deste artigo é apresentar breves considerações sobre as pesquisas que têm sido desenvolvidas no sítio arqueológico Sampaio, localizado no município de Felício dos Santos, Alto Vale do Araçuaí, Minas Gerais, e como se tem apropriado metodológica e teoricamente do conceito da paisagem para se inferir acerca de questões caras à Arqueologia. É sabido que os seres humanos coexistem com os outros agentes de seu meio sob uma ótica de percepção. Por isso, o sítio, o meio envolvente e os grafismos são analisados de acordo com discussões teóricometodológicas e de reflexões sobre as interrelações entre Humanos e o (seu) mundo, que podem contribuir para com o entendimento de como as pinturas se deram sobre a superfície rochosa e influenciaram o comportamento e processo de conhecimento daqueles que as realizaram. Utilizando diferentes metodologias, com investigações que seguem desde a caracterização geoambiental ou uso do SIG para mapeamento da área, tem-se buscado compreender a dinâmica das ocupações humanas em longa duração, tendo paisagem e lugar como conceitos-chave.

Palavras-chave: Arte rupestre. Paisagem. Lugar. Estrutura. Alto Araçuaí.

\begin{abstract}
The study in rock art has taken different perspectives in Archeology, within which its relations with the landscape. In this way, the objective of this article is to present brief considerations about the researches that have been developed in Sampaio archaeological site, located in the municipality of Felício dos Santos, Alto Vale do Araçuaí, Minas Gerais, and how we have methodologically and theoretically appropriate the concept of the landscape to infer about important issues for Archeology. It is well known that human beings coexist with other agents of their environment from a perspective of perception. Therefore, the site, environment and the paintings are analyzed according to theoretical-methodological discussions and reflections on the interrelationships between Humans and their world, which can contribute to the understanding of how the paintings were made on the rock surface and influenced the behavior and knowledge about the process of those who performed them. Using different methodologies, with investigations ranging from the geoenvironmental characterization or the use of GIS to mapping the area, we have sought to understand the dynamics of human occupations in long term, having landscape and place as key concepts.
\end{abstract}

Key words: Rock Art. Landscape. Place. Structure. Araçuaí Valley. 


\section{INTRODUÇÃO}

Em Arqueologia, muitas vezes (ou a maior parte das vezes), o fenômeno observado diz respeito aos Outros, que passaram, se deixaram, que morreram e que, ao longo da vida, estabeleceram marcas que os identificam como agentes e membros de uma sociedade. Neste emaranhado de comportamentos é o modo que se pretende concebê-los (os Outros), onde material e imaterial constituem um só, em que ideias e marcas (registros) são um todo, vistos como fontes inesgotáveis de análises e interpretações. Para tal intento, tem-se buscado a articulação de diferentes estudos e perspectivas sobre o comportamento humano, de maneira que se possa desenhar uma linha reflexiva sobre os modos como a humanidade se percebe e se insere no âmbito de sua própria criação, ou seja, o próprio mundo visto pela ótica da cultura.

A análise aqui proposta pretende ser interpretativa, à procura de significados, significações e sentidos que possam ser observados, descritos e analisados à luz da Arqueologia, onde a presença destes agentes se faz de maneira sutil, representada pelo repertório cultural, de toda e qualquer ordem, que foi deixado e permaneceu ao longo do tempo e, muitas vezes, refeito ou reinterpretado por outros grupos que passaram ou se estabeleceram na mesma área. Trata-se de um continuum cultural em que o lugar é o conceito-chave, percebido e experimentado ao longo do tempo, um alicerce importante para a construção da memória social ou mesmo das diferentes ontologias sobre o mundo.

Sendo assim, o sítio arqueológico Sampaio foi percebido como um documento/ monumento, no sentido que ele é tanto uma herança, uma representação e um registro de histórias (LE GOFF, 1990). Para tanto, foi considerada a necessidade de analisar seus painéis rupestres e o modo de organização da (s) ocupação (ões) do abrigo, atentando-se às suas estruturas, uma vez que são o resultado de uma montagem daqueles que os produziram e dos que depois neles se representaram, ainda que pelo silêncio.

Os agentes não foram entendidos como indivíduos independentes e desconexos, pelo contrário, foram percebidos como integrantes de uma realidade: a sociedade. Um todo maior, coeso, mas não necessariamente coerente, que forma um sistema: “(...) que tem suas próprias leis e normas. Normas que, se obviamente precisam dos indivíduos para poderem se concretizar, ditam a esses indivíduos como devem ser atualizadas e materializadas” (SOUZA, 2015, p.78). Também não foram considerados como marionetes de um organismo abstrato, visto que a arte rupestre foi percebida como uma expressão da humanidade que toma consciência de si mesma e se evidencia, por meio do uso do corpo, “[...] a mais tangível manifestação social” (SOUZA, 2015, p. 200).

Neste artigo os grafismos rupestres do sítio Sampaio foram tratados como evidência de um processo de produção e ação (um continuum), sob um pensamento coletivo e individual que 
manifesta um sistema de lógicas e regras. Consequentemente foram considerados parte desse processo que não se iniciou, nem se findou, no que foi eleito para ser inscrito/ pintado na superfície rochosa, construindo paisagens e definindo lugares que permitem/ estabelecem sentido à vida em si ou, como destacado por Troncoso (2001), entender a “(...) paisagem como um lugar para a práxis e socialmente significativo".

Nosso objetivo, portanto, é apresentar os resultados da pesquisa que teve como norte teórico-metodológico o conceito de paisagem e suas implicações para a pesquisa em Arqueologia.

\section{DOS MODOS DO MUNDO ONDE SE DERAM A AÇÃO - CONSIDERAÇÕES CONCEITUAIS E PRÁTICAS SOBRE O SÍTIO E SEU ENTORNO}

Como ressaltou Geertz (1998), toda ação humana está intimamente relacionada ao seu tempo e meio, sendo impossível analisá-la sem se ter em consideração tais fatores. As atividades sociais e individuais se realizam em coexistência com os modos do ambiente em que se constituem. Assim, por meio das reflexões sobre as inter-relações entre comportamento humano, os demais agentes e formas do mundo, as características topogeoambientais da área de inserção de Sampaio podem ser entendidas, de modo a serem válidas à discussão sobre a arte rupestre.

O sítio Sampaio é um abrigo sob rocha quartzítica implantado em alta vertente (Serra do Jambreiro), com elevação de 757 metros acima do nível do mar, localizado em terras do município de Felício dos Santos, Minas Gerais, no Alto Vale do Araçuaí, Bacia Federal do Jequitinhonha. O sítio foi escavado no ano de 2016, onde foram executados 13 níveis (até o embasamento rochoso), com profundidade de $44 / 46 \mathrm{~cm}$, muito mais profundo que a maioria dos sítios escavados regionalmente (Figura 01).

Ao todo foram evidenciados 03 pacotes de ocupação, sendo que a estrutura 03 (nível 09 , camada de ocupação 03, no perfil SW), foi datada por Carbono 14 no laboratório Beta Analytic (Miami, EUA), resultando em uma cronologia de $4280 \pm 30$ anos AP (BETA 471280 - data nãocalibrada).

Sua inserção se dá em área de Bioma do Cerrado e, de acordo com a classificação de GiegerKöppen, com predomínio do clima mesotérmico (Cwb), marcado por verões brandos e úmidos e invernos mais frescos e secos. Os índices de precipitação variam de $1250 \mathrm{~mm}$ a $1550 \mathrm{~mm}$ e temperatura média anual não ultrapassa os $20^{\circ} \mathrm{C}$, tendo uma variável entre $18^{\circ}$ a $19^{\circ} \mathrm{C}$. Mesmo estando no Bioma do Cerrado, hoje seu entorno direto é marcado pela presença de matas (Floresta Estacional Semidecídua), comum às encostas da Serra do Jambreiro (FAGUNDES et al., 2017).

O sítio é margeado pelo córrego Sampaio, afluente do Araçuaí (Bacia Federal do Jequitinhonha). A presença de cursos d'água, associado ao local de inserção do sítio neste ambiente, é um dado relevante, uma vez que, além de serem fontes hídricas, estes cursos são meios de 
obtenção de outros recursos de subsistência, como pontos de oportunidade de pesca e caça. Ademais, podem ser utilizados como caminhos e marcos, ambos referenciados geograficamente. Sendo pontos fixos e interconectados, eles podem funcionar como uma rede de conexão ambiental, geográfica, social e, principalmente, simbólica.

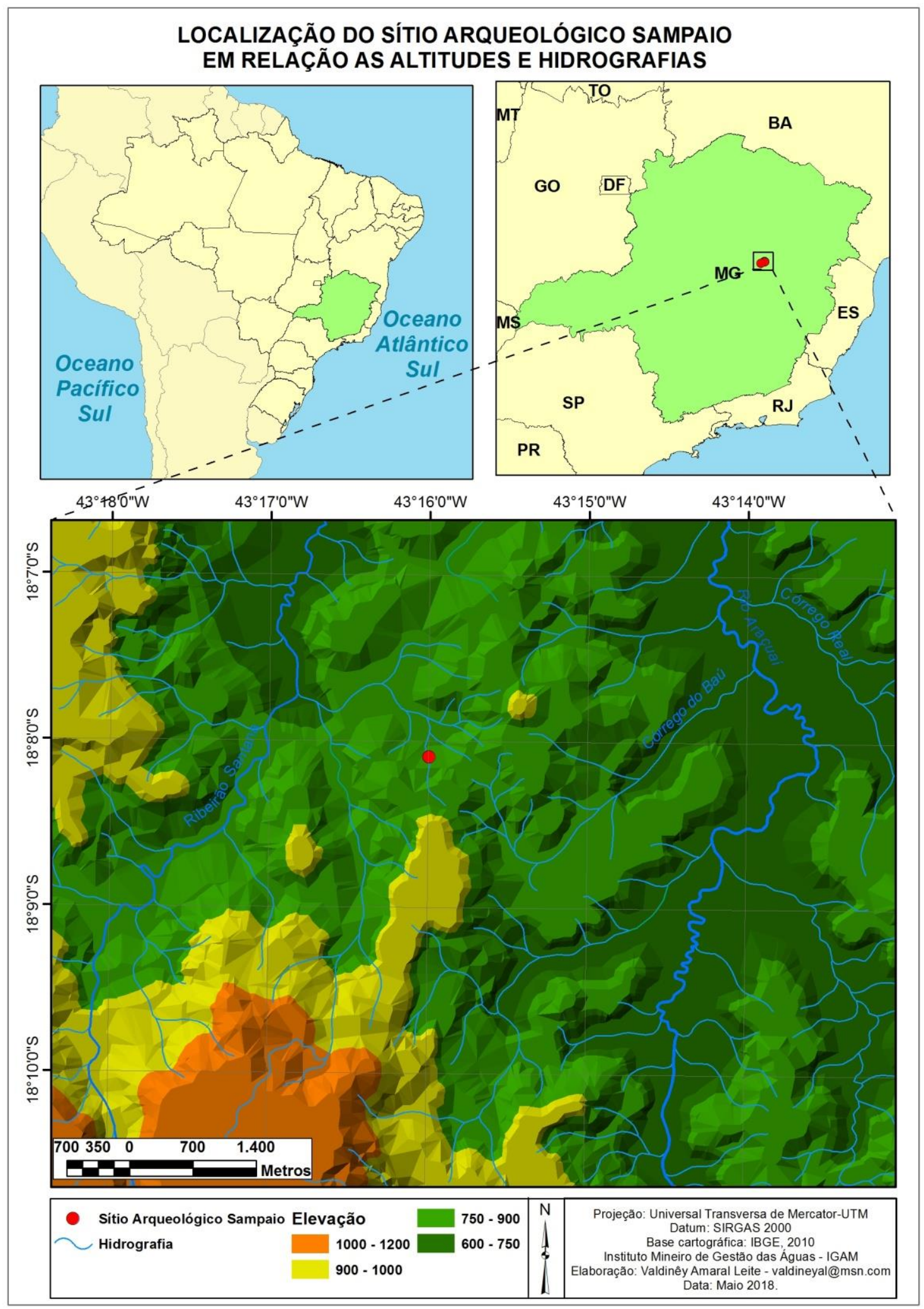

Figura 01 - Localização do Sítio Sampaio. Fonte: Amaral/2018. 
Os grafismos, por serem produto da cultura, ou seja, a materialização de uma forma de pensamento, exigem em suas análises a investigação das relações entre cultura e natureza, logo, entre agentes diversos. O estudo das relações entre humanidade e meio leva à análise das condições de coexistência e transformação recíproca reveladas na cultura material, produto da relação e mediação entre uma determinada sociedade e seu sistema tecnológico e simbólico (TRONCOSO, 2001). Não obstante, mesmo que as representações se adicionam e se sobrepõem a seus fundamentos materiais, elas não provem diretamente deles (RODRIGUES, 1975).

Em algumas culturas, por exemplo, um animal não era ou é tomado ou conhecido como um ser biológico “[...] devido a seu duplo caráter de organismo - vale dizer, de sistema - e de emanação de uma espécie, que é um termo dentro de um sistema, o animal aparece como um instrumento conceitual de múltiplas possibilidades", atuando em qualquer domínio, em sincronia ou diacronia, concreto ou não (LÉVI-STRAUSS, 1989, p. 169).

Ao nível do indígena, a categoria de 'Natureza' é um fato cultural; o 'natural' confunde-se com o culturalmente definido como natural. Variável culturalmente, a categoria de 'Natureza' é particular a cada sociedade e tem muito a ver - ao mesmo tempo como causa e consequência - com as relações que cada sociedade mantém com a Natureza real (RODRIGUES, 1975, p. 21).

Assim

Não basta identificar com exatidão cada animal, cada planta, pedra, corpo celeste ou fenômeno natural evocado nos mitos e no ritual - tarefas múltiplas para as quais o etnólogo raramente está preparado - é preciso saber também que papel cada cultura lhe atribui no interior de um sistema de significações. Ora, é necessário saber quais, pois essas relações não são constantes de uma sociedade para outra e para a mesma espécie (LÉVI-STRAUSS, 1989, p. 70).

Ainda que utilizem de técnicas e objetos iguais, não significa, precisamente, que determinados grupos pensam e se comportam da mesma maneira. Mesmo que estejam muito próximas, cada cultura constrói um sistema único, inteiramente diferente de outros, apesar de apresentarem elementos que parecem ser idênticos ou semelhantes (LÉVI-STRAUSS, 1989).

As formas da natureza (ou seja, os outros agentes existentes no cosmos) se constituem como são conhecidas a partir dos sentidos dos indivíduos que as contemplam e lhe caracterizam. As formas do mundo, para além da pessoa, são segundo ela, mas não são ela, existem independente de suas percepções. A natureza existe em si, ela é antes à humanidade, todavia, afastada da atividade humana ela é sem forma e sentido (COSGROVE, 1998).

Existem relações constantes entre o observador e aquele que estimula a observação e a significação, por meio da atribuição de sentido, na letra de Ingold (2002, p.14): “(...) os seres humanos habitam mundos discursivos de significado culturalmente construídos, estando um passo 
para fora do mundo da natureza dentro do qual as vidas de todas as outras criaturas estão confinadas"1.

O entendimento da relação entre Natureza e Cultura, das formas de intervenção e relação dos Humanos com o seu meio, é um método analítico que geralmente pressupõe a corrente dicotomia entre esses cantos. Contudo, como ressalta Eduardo Viveiros de Castro, esta distinção não deve ser feita quando se trata de cosmologias não-ocidentais (o caso do nosso objeto de estudo), uma vez que “(...) as categorias de Natureza e Cultura, no pensamento ameríndio, não só não subsumem os mesmos conteúdos, como não possuem o mesmo estatuto de seus análogos ocidentais; elas não assinalam regiões do ser, mas antes configurações relacionais, perspectivas móveis, em suma - pontos de vista (VIVEIROS DE CASTRO, 2006, p. 241). Ainda de acordo com o antropólogo acerca do pensamento ameríndio, ele prossegue,

[...] tendo outrora sido humanos, os animais e outros seres do cosmos continuam a ser humanos, mesmo que de modo não-evidente. A condição original comum aos humanos e animais não é a animalidade, mas a humanidade. A grande divisão mítica mostra menos a cultura se distinguindo da natureza que a natureza se afastando da cultura: os mitos contam como os animais perderam os atributos herdados ou mantidos pelos humanos [...] Os humanos são aqueles que continuaram iguais a si mesmos: os animais são ex-humanos, e não os humanos ex-animais (VIVEIROS DE CASTRO, 2006, p. 245).

Aqui se compreende que as características e formas do mundo têm relevância por serem consideradas como agentes de uma coexistência em relação intrínseca com a humanidade. Por isso, acreditamos que elas não podem ser observadas de modo separado dos humanos ou ao menos da consciência de sua existência. São os Humanos que percebem e caracterizam o meio em que estão inseridos (em sua materialidade e imaterialidade). Os outros modos e agentes existentes se relacionam com eles e são fatores em sua existência não sob processos de relação direta, mas sob camadas de percepção e significação, que produzem a identificação e caracterização deles. É essa existência constituída que afeta a humanidade.

A própria natureza só se define, em suas múltiplas faces, a partir do momento que é percebida, uma vez que se caracteriza por um conjunto de formas físicas dispostas sem sentido. Quando o olhar atribui significado ao que contempla, a realidade se torna para o observador, em relação a ele, de modo organizado e impregnado de sentido. A natureza vista de modo sistemático é o que se entende por ambiente (INGOLD, 1993).

Nesta perspectiva (por si só, o dado pelo dado), o fato de o solo local ser caracterizado como Argissolo Vermelho Amarelo Distrófico, considerado um dos mais profundos da região de Felício dos Santos ou a vegetação da área ser identificada como um ecótono, onde se pode observar fitofisionomias de cerrado e mata ,pode ser tornar uma informação pouco relevante se não houver

${ }^{1}[\ldots]$ that human beings inhabit discursive worlds of culturally constructed significance is to imply that they have already taken a step out of the world of nature within which the lives of all other creatures are confined. 
um entendimento das relações entre estas características, o registro arqueológico e os Humanos. Em suma, não basta a caracterização geoambiental se ela não dialoga com o registro arqueológico, com a cultura material, com os Humanos em si.

Neste sentido que se firma nossa afirmação de que o ambiente coexiste junto à cultura. A sociedade não é independente dos objetos geográficos que, apesar de não a definirem, a limita ou favorece, não apenas por seus aspectos geomorfológicos, fitogeográficos ou hidrográficos, mas, e talvez principalmente, porque eles próprios existem sob uma ótica cultural, onde em cada forma se encerra valores de uma sociedade. O ambiente é a natureza repleta de significados e, mais que (ou tanto quanto) os aspectos topogeoambientais em si, são eles que têm grande efeito sobre os agentes. Como ressaltou Protágoras, “(...) o Homem é a medida de todas as coisas”. É por meio dessa medida que tudo existe, pode existir, ou não.

O ser humano deve ser entendido enquanto o agente social, psicológico e fisiológico, sendo impossível a compreensão do seu comportamento de modo fragmentado, sem alguma dessas categorias em consideração (MAUSS, 1979). É sempre o "Homem Total" que, em sua indivisibilidade, existe e age, de modo a atender os seus interesses e necessidades (FAGUNDES, 2014).

A partir de uma herança cultural, instrumental e técnica transmitida por meio da tradição, cada grupo constitui sua maneira de ser, seu modo de vida, que possibilita a habitação no meio e a satisfação de suas necessidades fisiológicas. Cabe salientar que, habitar não é ocupar (INGOLD, 2002). Habitar não é um simples viver sobre, mas existir através.

A natureza se humaniza, se carrega de (re) significados por meio do uso humano, em um processo contínuo (em longa duração). As técnicas influenciam o modo como o ambiente e o tempo são percebidos, não só por causa de suas relações com o meio físico, mas também pela maneira como afetam as percepções e sensações do grupo em que operam. A humanidade não apenas age na natureza, mas interage com e sobre ela por meio da técnica e de suas relações de significação e produção de sentidos (INGOLD 1993). Assim, a realidade vivida se dá não como uma simples criação de uma imaginação humana, mas como o encontro entre sujeitos e objetos, entre o dado e o que é sensível (COSGROVE, 1998; SERPA, 2013).

Tal encontro é o que constitui a paisagem, que se integra à dinâmica social e a cosmovisão, sendo ao mesmo tempo construção e agente de construção de si mesma e daqueles que sob seus sentidos a constituíram. Ela se revela numa experiência entre objetos, formas e percepções que são históricos, ambientais, contextuais e mensurados a partir do próprio agente que a observa. Uma vez que sua construção não se dá apenas no campo da visão, mas também nos sentidos e valores simbólicos, a paisagem inclui em suas morfologias o que tem valor para diferentes sujeitos. Todavia, como destacado por Anchuetz et al.. (2001), a paisagem não é a soma de ambientes 
construídos, mas podem ser entendidas como a maneira em que as pessoas têm significado a si mesmas e o mundo, sendo palco de todas as atividades em sociedade.São construções dinâmicas, vistas como um texto histórico e que funcionam como um sistema de manipulação simbólica (FAGUNDES, 2014).

Há entre diferentes concepções e uso do conceito uma concordância que as paisagens são construídas a partir das dimensões sócio-simbólicas (e cosmológicas) e, desta forma, estão além da dimensão física, característica que permite que estas paisagens sejam experimentadas, percebidas e contextualizadas (KNAPP; ASHMORE, 1999). Ou, como destacado por Zvelebil (1997), o conceito de paisagem une características do mundo real/ percebido, natural e cultural, e, para além das formas físicas exclusivamente, permitem especificidades à forma da Terra. IDe acordo com Anchuetz et al.. (2001), as discussões do que o conceito significa são extensas, mas, como temos realizado em outros trabalhos, a paisagem é aqui compreendida exclusivamente como um produto cultural, moldadas pelas experiências ao longo do tempo. Traz consigo um potencial interpretativo valioso às pesquisas em Arqueologia, uma vez que trata de relações e expressões humanas no tempo e no espaço.

Como Cosgrove (1998) salienta, a paisagem possui múltiplas "camadas de significados", somatórias de tempos, que tem muitas dimensões e possibilidades de leituras. Ela é o mundo como ele é conhecido e sentido por aqueles que nela experimentam, habitam, se movem e dão sentido a todas as coisas, uma vez que, cada grupo possui padrões próprios de atribuição e uso da paisagem, de ordem cosmológica, ética/ moral, religiosa, política, econômica, social, estética, etc., em dimensões físicas e simbólicas.

Ou seja, em virtude de sua essência, produto e produtora, "marca" e "matriz" de cultura, a paisagem é dinâmica (BERQUE, 1984). As "formas", "os objetos geográfico", repletas do "conteúdo", de "frações da sociedade em movimento", são, continuamente, (re) significadas, reinseridas, reaprendidas e (re) apreendidas, a cada percepção, a cada olhar, ainda que pelo mesmo indivíduo, por isso elas não podem ser entendidas como uma simples "materialização de um instante da sociedade", como a caracterizou o geógrafo brasileiro Milton Santos (2010).

Entendemos que a paisagem é uma estrutura plurimodal, sendo, ao mesmo tempo, passiva, ativa e potencial (BERQUE, 1984). Por isso, ela está em um processo perene de desenvolvimento ou de dissolução e substituição. Assim, ela nunca é a mesma, uma vez que um único grupo ou pessoa pode, ao longo de sua existência, em decorrência de sua própria dinâmica, atribuir-lhe diferentes significados e importâncias, lhe trazendo outros sentidos. Estruturada e estruturante, a paisagem representa o agente enquanto tal e sua ação no meio envolvente. Em outras palavras, ela é o contexto visual da existência humana (BERQUE, 1985). 
Por isso Ingold (1983, p. 7) indica que a paisagem como um testemunho de diferentes Humanos que a habitaram e que, neste sentido, acabaram por deixar marcas daquilo que foram que, sob nosso ponto de vista, se dá tanto no campo material como das ideias ${ }^{2}$. Por isso, ela configura-se como "documento-chave" para a compreensão dos modos de existência, no qual função, forma e estrutura são elementos centrais (CLAVAL, 2007). O conceito não se caracteriza unicamente pelo o que se vê, por aquilo que está à frente dos olhos, mas, também, pela maneira como se percebe, sente e age. A paisagem se manifesta repleta de significados que orientam, direcionam e limitam a ação humana, em lógicas provenientes de diferentes escalas, determinantes e determinadas por específicos agentes sociais que dela se apropriam (FAGUNDES, 2014).

O observador é o centro da espacialidade, seu ponto zero, uma vez que por meio de seus sentidos, a humanidade (se) percebe e se coloca em ação sobre e através do meio, sem ao menos ter operado nele, de modo a interferir em suas formas. A sociedade define seus tempos, limites, comportamentos e possibilidades, em processos de significação, onde o objeto natural se torna cultural, sem ao menos ter sido tocado. Todos os lugares são resultados de concepções, percepções e esforços (COSGROVE, 1998; MARIA, 2010; COLLOT, 2012).

Portanto, as paisagens não são apenas as formas em ação, mas as formas das ações; não somente o movimento da sociedade, mas a sociedade em constante movimento. Tais relações são simbolicamente orientadas e envolvem escolhas, que estão diretamente associadas ao modo de ser e estar, no e pelo mundo, relacionadas aos sentidos, apego sentimental, à memória, ao mito, como lugares de (re) visitação (morada da ancestralidade, dos deuses) até dos caminhos/ fronteiras que se pode ou não prosseguir, enquanto espaços do sagrado ou do profano (FAGUNDES, 2014).

Em processos subjetivos, coletivos e particulares, de interação com o meio, os Humanos estabelecem a construção da paisagem, a partir tanto das possibilidades e perspectivas que a apropriação do ambiente permite, quanto de itens que vão além da materialidade das coisas. Nesta perspectiva, todas as paisagens estão compostas por camadas de materialidade (de suas formas) e por aquelas camadas mais fluidas, de caráter abstrato, mas tão perceptível quanto (estruturas).

Para Tuan (1983), a título de exemplo, a experiência é parte fundamental deste processo de dar vida e, portanto, sentido à natureza, visto que o "aprender" se dá pela vivência, uma vez que: "Experienciar é aprender; significa atuar sobre o dado e criar a partir dele. O dado não pode ser conhecido em sua essência. O que pode ser conhecido é uma realidade que é um constructo da experiência, uma criação de sentimento e pensamento" (TUAN, 1983, p.10).

\footnotetext{
${ }^{2}[\ldots]$ The landscape is constituted as an enduring record of - and testimony to - the lives and Works of past generations who have dwelt within it, and in so doing, have left there something of themselves ((INGOLD, 1993, p. 152).
} 
A paisagem é uma expressão humana intencional ${ }^{3}$ que possibilita, direciona ou condena maneiras de ver, de compor, harmonizar, identificar e intervir no e pelo mundo, uma vez que é integrada aos sentimentos dos indivíduos por meio dos processos cognitivos, da formação social, sob lógica e propósitos específicos que visam à manutenção da ordem e harmonia do/no grupo (ainda que sejam inconscientes, entendidos enquanto somáticos) (COSGROVE, 1998, p. 222; BERQUE, 1985).

A paisagem, por um lado, é um campo visto por um olhar, apreendido por uma consciência, reforçada pela experiência, tida (e possivelmente reproduzida) por uma estética e ética, gerida por uma política, etc.; por outro lado, ela é uma matriz, uma vez que determina, por sua vez, esse olhar, essa consciência, essa experiência, a estética e a moral, esta política, etc. (BERQUE, 1984, p.33) .

De volta ao abrigo Sampaio (levando em conta estas considerações), sua implantação é muito discreta, em meio uma vegetação densa, de árvores com dossel arbóreo maior que o esperado para o cerrado regional, cobertura vegetal classificada como uma mancha de Floresta Estacional Semidecidual. Em virtude disso, a sua visualização a partir das condições topogeoambientais atuais se mostra difícil, quase que imperceptível em quase todo o entorno. O relevo local é ondulado e marcado por quebras topográficas que formam vales e depressões, onde a vegetação é mais densa e há presença de pequenos cursos fluviais perenes ou não. Nas caminhadas até o sítio (e em seu entorno), apesar de existirem trilhas e pontos já reconhecidos e reconhecíveis pela equipe, o grupo se perdeu em algumas vezes. Era (e é) preciso parar, observar e caracterizar todo o meio circundante de modo a lhe conferir lógica e sentido, ações que ajudassem na identificação de um (possível) trajeto que ligava ao abrigo (Figura 02).

Apesar de, a partir de uma observação no solo, parecer difícil a sua identificação/distinção entre a vegetação e outros afloramentos, apenas sobre o sítio, do teto do abrigo, que é possível ter uma ampla contemplação de seu entorno. Contudo, além de não se dar em uma análise comparativa, esta pesquisa partiu da prerrogativa que, ainda que existam recorrências e semelhanças entre as características de abrigos e implantações de sítios, todas as relações que se deram e motivaram essas escolhas, não foram em vias diretas de observação, mas em entrelinhas indiretas de atribuição de conceitos e sentidos. As pessoas antes de tudo sentem o mundo (a paisagem enquanto mundo do vivido), elas percebem, classificam e moldam o meio circundante por meios de um emaranhado de

\footnotetext{
${ }^{3}$ Que não é sinônimo de uma ação "consciente", pelo contrário é ato que faz com que o pesquisador se volte para o fenômeno, permitindo que ele se manifeste enquanto tal. Uma ampla discussão sobre hermenêutica e arqueologia e, por ínterim, processos de intencionalidade é feito por Johnsen e Olsen (1992).

${ }^{4}$ Il faut comprendre le paysage entant, d'une part, qu'ilest vu par un regard, appréhendé par une conscience, valorisé par uneexpérience, jugé (et éventuellementreproduit) par uneesthétique et une morale, géré par unepolitique, etc.; et d'autre part entant que matrice, c'est-à-dire entantqu'ildétermineen retour ce regard, cette conscience, cetteexpérience, cetteesthétique et cette morale, cettepolitique, etc.
} 
sentidos e significados, relacionados diretamente a cosmovisão, bem como os aspectos de ordem moral, jurídica, religiosa e/ou simbólica.
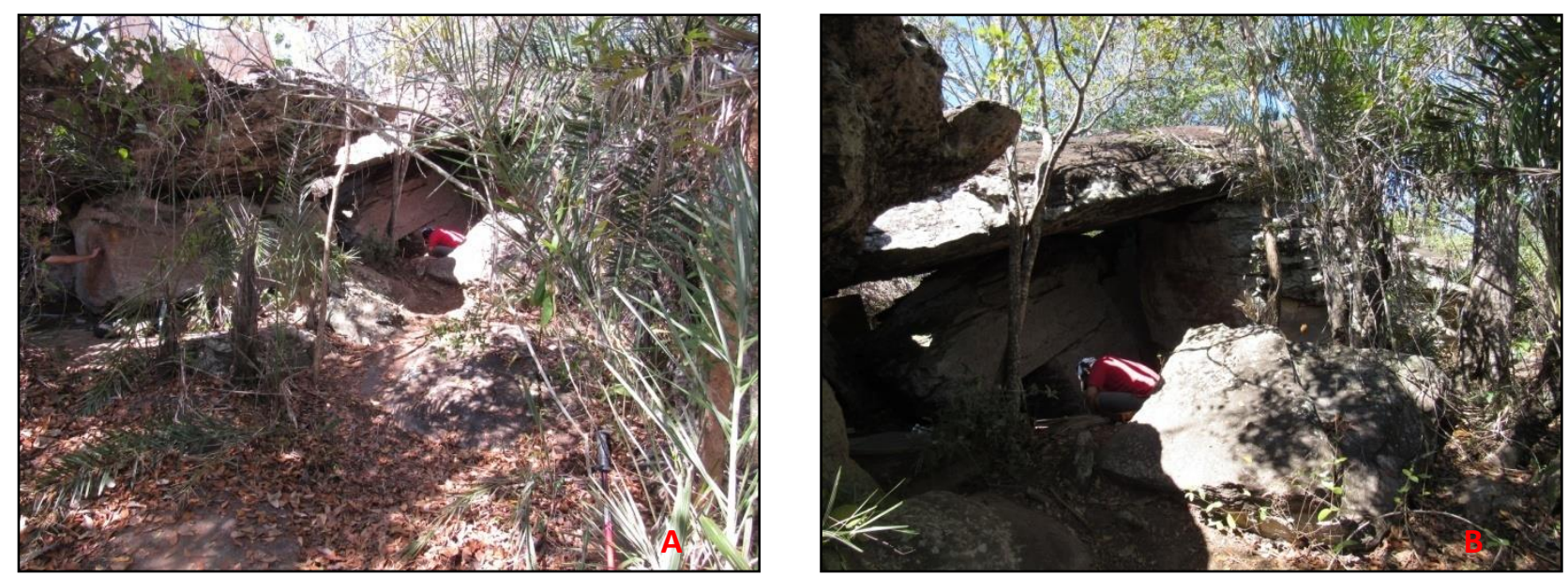

Figura $02(\mathrm{a} / \mathrm{b})$ Vista a partir do abrigo e do abrigo.

Fonte: Autor/2017.

O abrigo está localizado na porção nordeste da Serra do Jambreiro, sendo que em toda a vertente foram identificados blocos quartzíticos em superfície e a formação de outros abrigos na serra. Todavia, até então, nessa porção da Serra, apenas o Sampaio foi identificado com pinturas, o que não elimina a hipótese que o(s) mesmo(s) grupo(s) que o ocupou (ram) também tenha(m) utilizado outros abrigos e áreas abertas para atividades de outros fins, muito menos que outros pontos tivessem significados e significações para ele(s).

O abrigo possui dois compartimentos, ambos com painéis rupestres. Contudo, tal divisão é meramente analítica e possivelmente, se existente, não se deu na mesma lógica por outros que já o ocuparam. É preciso enfatizar que o abrigo rochoso é um recorte de análise desta pesquisa. Em grande parte, pode-se supor que as atividades e relações que nele ocorreram certamente não se limitaram a ele, pelo menos enquanto estrutura física. Os limites dos lugares se dão para além da geomorfologia ou do alcance de visadas, eles são constituídos nas relações entre as pessoas, as ações e os modos da morfologia do meio (Figura 03).

Assim, eles não são apenas físicos, mas também discursivos. Existem dimensões do sagrado e do profano, do público e do privado, do habitável ou não, do leito, da cozinha, do lazer, etc., definidas culturalmente, que orientam, limitam e/ou condicionam, além dos métodos, objetos e tempos, os espaços de ação, intervenção e uso, segundo a lógica de cada grupo social (FAGUNDES, 2014). Registram-se neles os modos de ocupação, ou seja, a moral, a técnica e conhecimento de um grupo. 


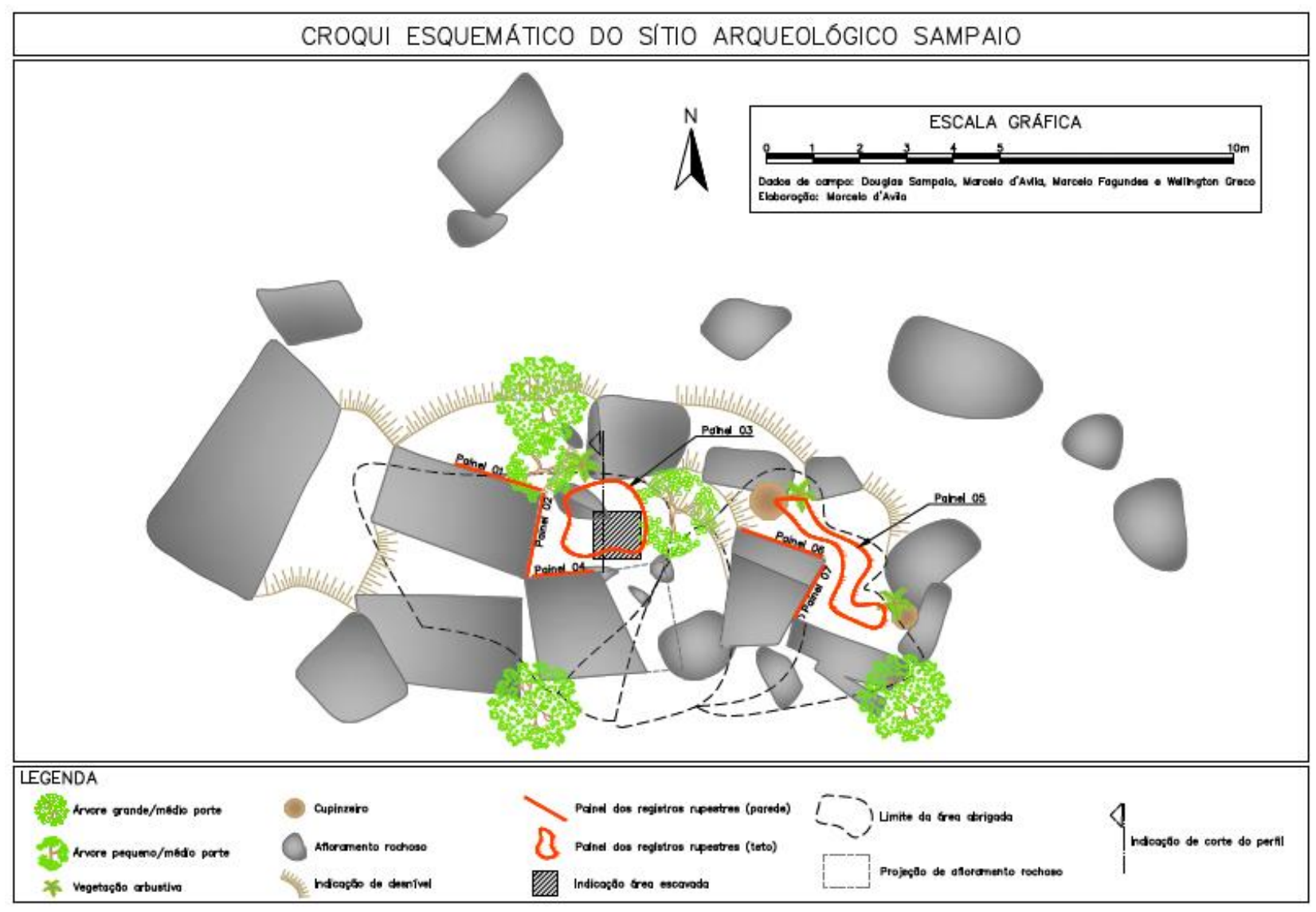

Figura 03 Croqui esquemático do sítio Sampaio.

Fonte: Aroeira/2017.

Por diversas vezes os lugares foram (e são) (re) definidos, (re) delimitados e (re) significados. Eles são dinâmicos e se transformam, assim como a humanidade neles, em processos de coexistência e (re) significação mútua (ALVES, 2013/14). Por isso, eles também podem ser tomados como testemunhos de usos, encontros, contatos e interações no grupo e entre grupos diferentes (RIBEIRO, 2006; LINKE, 2008).

\section{RESULTADOS E DISCUSSÕES: A ARTE RUPESTRE DO SÍTIO SAMPAIO}

Todas as atividades humanas são, ao mesmo tempo, materiais e simbólicas, sendo produção, representação e comunicação. Em qualquer ação técnica (do lugar, da época de extração da matériaprima escolhida até a vestimenta dos indivíduos envolvidos no procedimento) todo o processo (que segue desde a idealização, construção, utilização até descarte ou destruição de vestígio) é repleto de significação. Segundo nossos pressupostos, esta significação é definida, ou ao menos possibilitada, pela tradição de um povo que lhe atribui valores culturais identificados socialmente, sob uma lógica própria. 
[...] se as diferentes produções materiais, e imateriais, de uma sociedade não guardam uma coerência, uma compatibilidade estrutural entre elas (mas não uma determinação), se não se ajustam em um mesmo princípio de inteligibilidade, deixam de ser eventos culturais e perdem toda sua eficiência social e simbólica ao ser de impossível decodificação por um receptor (TRONCOSO, 2002, p. 70-71) .

Cada sociedade e seu conjunto de costumes são sempre marcados por um estilo, que formam sistemas (LÉVI-STRAUSS, 1957). A sociedade muda as formas do não humano, tido como natural, em instrumentos de humanização, por meio do ritmo técnico que humaniza a própria matéria-prima. As formas do fazer e do feito são produto e marca desse corpo humanizado. Não se trata apenas produto de uma cultura, de relações e dinâmicas sociais. São as representações de uma maneira de fazer, de (se) entender e de (se) sentir enquanto humano, peculiares a uma sociedade (LEROIGOURHAN, 1971).

A sociedade é um campo de significação, onde os corpos dos indivíduos são suportes de um sistema simbólico que os humanizam, na medida em que se vestem dos símbolos da sua razão de ser (VIVEIROS DE CASTRO, 2006). Elas procuram um determinado modo de fazer, sendo que este fazer de tal modo é, em um mesmo ato, fazer-se de determinada maneira e se representar como tal: individualizar-se (como pessoa ou grupo).

Com estas ideias em mente partimos do pressuposto que, além de ser as marcas que 'lugarizam', a arte rupestre é vestígio dos modos de (se) fazer, além de ser e estar no mundo. Seu estudo direciona reflexões sobre diferentes âmbitos da realidade humana e social no passado. Esta pesquisa, em primeiro momento, voltou-se para a análise dos modos de organização dos grafismos rupestres no sítio. Para tanto, primeiro o sítio foi sistematizado arbitrariamente em diferentes painéis. Cumpre ressaltar que tal organização só pode ser considerada como uma estratégia metodológica primeira de tratamento dos elementos materiais de cultura. Neste artigo, em especial, nem todos os painéis são discutidos, uma vez que se considerou mais pertinente a escolha de um número menor que possa contribuir com discussões mais adequadas da temática que buscamos apresentar neste artigo. Assim, os painéis 3 e o 4 foram os escolhidos por representarem grafismos ameríndios e intervenções recentes, aliás as únicas identificadas no sítio.

Sendo a arte rupestre um dos poucos vestígios arqueológicos que se encontram exatamente no lugar onde foram feitos, acreditamos que, não apenas as pinturas eram direcionadas a um fim pré-concebido, como também o próprio painel foi estruturado segundo um ordenamento que possibilitava a compreensão do todo e das partes. Cada grafismo não é um todo isolado, mas termos

${ }^{5}[\ldots]$ si las diferentes producciones materiales, e inmateriales, de una sociedad no guardan una coherencia, una compatibilidad estructural entre ellos (más no una determinación), sino se ajustan a un mismo principio de inteligibilidad, dejan de ser actos culturales y pierden toda su eficacia social y simbólica al ser imposibles de decodificar por un receptor. 
que se inserem em um universo maior que é o painel e este, bem como o sítio, tornam-se um lugar, um marco paisagístico que orientou (e orienta) pessoas em seus mundos.

De acordo com Lévi-Strauss (1985, p. 233), “[...] o símbolo tira a sua significação do contexto, de sua relação com outros símbolos que, do mesmo modo, só ganham sentido em relação a ele". Assim, sua significação não existe, em si, no absoluto; ela é, somente, de posição. Os traços e as formas das pinturas não são aleatórios, eles visam um fim que é próximo à reprodução mental do objeto pronto.

Desde o primeiro traço, todo o processo de construção da arte se direciona ao seu resultado, à obra acabada (LÉVI-STRAUSS, 1983).

Nesse sentido, é o estabelecimento de relações entre os termos que possibilita a significação, tanto do contexto como dos objetos. Não são apenas os traços e formas que são conscientemente elaborados, mas também o lugar e interações com os outros termos que também foram cuidadosamente explorados. As constituições dos traços se deram com vistas à forma final dos grafismos, assim como estes se fizeram em relação ao já existente, já pinturas, o meio entorno ou a própria pedra, a superfície rochosa, que a primeira camada de significado e relação no ato de grafar. Ou seja, as relações entre os grafismos podem ser consideradas como ações sincrônicas, mais que diacrônicas. A construção dos painéis não foi percebida como uma sobreposição de etapas desconexas, mas como uma justaposição de interferências contínuas, ainda que as relações e interações entre os termos sejam apenas indiretas ou em pequenas razões (LÉVI-STRAUSS, 1985).

Em função desta imobilidade dos painéis, acredita-se que, não apenas as pinturas eram direcionadas a um fim pré-concebido, como também o próprio painel foi estruturado segundo uma ordem específica que possibilitava a compreensão do todo e das partes. Cada grafismo não é um todo isolado, mas termos que se inserem em um universo maior que é o painel. Acredita-se que, por isso, o seu significado (expresso na forma), não apenas reside em si, mas em sua relação com os outros, por meio da observação daquele que os percebe.

O hiato temporal entre cada grafismo, se existente, é pouco relevante, uma vez que as pinturas, gravuras e objetos estão no tempo, não apenas no passado, ou melhor, no momento de execução. Sendo intervenções perenes, permeiam toda a linha do tempo, tendo um ponto de início (criação) e uma constância imensurável de existência, de vida (em todos os sentidos da palavra, como presença), que influencia, limita ou condiciona todas as demais ações, intervenções e sentimentos posteriores, inclusive, até mesmo, depois de serem, totalmente, descaracterizadas por intempéries. As pinturas se "apagam” e é nesse processo que o fator tempo se apresenta imperativo.

É indubitável o fato que pinturas anteriores influenciaram aquelas que as sucederam, porém, cabe ressaltar que o desenvolvimento da arte só pode ser explicado em termos que lhes são próprios. Ela se dá no instante de sua realização, nas percepções do(s) artista(s) sobre o mundo 
exterior e aquele momento. As pinturas, as formas dos traços, a intensidade do gesto, a posição corporal do agente e a composição da tinta a ser utilizada se dão/deram sob as percepções do agente, em um processo reflexivo em relação a tudo e ao todo, que não apenas está em sua volta, mas o submerge no conhecimento de si mesmo e dos outros, suas vontades, expectativas e limitações. Assim, pode-se considerar que, mais que o conhecimento de uma técnica, a arte é o conhecimento de toda uma dinâmica social. Em um mesmo tempo ela é ação, reflexão e conhecimento. O mundo como ele é considerado é uma construção simbólica, por isso é tão difícil mensurar formas, conteúdos e realidades (LÉVI-STRAUSS, 1983).

Em Sampaio foram identificadas intervenções mais recentes na parede do abrigo, que não se sobrepunham as pinturas ameríndias. Existem inscrições por cima da biopertubação feitas por meio de picoteamento (Painel 04). As gravuras possuem o formato de símbolos recentes e formam um registro de datação comum do tempo presente, onde os numerais que indicam o dia, mês e ano são separados por barras (14/12/00). Outros símbolos, mais próximos ao solo atual, formam uma palavra em português (SARAIVA) (Figura 04).

Apesar de não conter grafismos elaborados por populações ameríndias, o painel 4 é extremamente importante a este estudo. Ele é composto por traços ordenados que, assim como as pinturas, se constituem em símbolos associados por aproximação ou distanciamento. De acordo com Lévi-Strauss, nenhum símbolo, se tomado isoladamente, possui significado, visto que a significação só é dada a partir do momento que há relações, uma vez que: "Sua significação não existe no absoluto; é somente de posição" (LÉVI-STRAUSS, 1985, p. 243).

Pode-se inferir que não é apenas a forma do traço, mas a sua associação aos outros que possibilita a sua interpretação e o sentido do todo. Um traço isolado nada significa, mas se associado a outros dois, por exemplo, de modo ordenado, pode formar um símbolo como a letra A. Esse, em mesmo processo, quando estabelece relações com outros, de mesma natureza, constitui uma palavra.

Diferentemente dos símbolos identificados nos painéis 1,2 e 3, os presentes no painel 4 estão sob uma lógica que pode ser evidenciada, por ser conhecida. De modo algum se pretende equiparar os grafismos à escrita atual, isso seria limitar a arte e seu potencial. Contudo, cumpre ressaltar que os símbolos possuem uma lógica própria que tem sentido dentro de um contexto cultural específico, como discutido alhures, o que é o caso das gravuras do painel 4. 


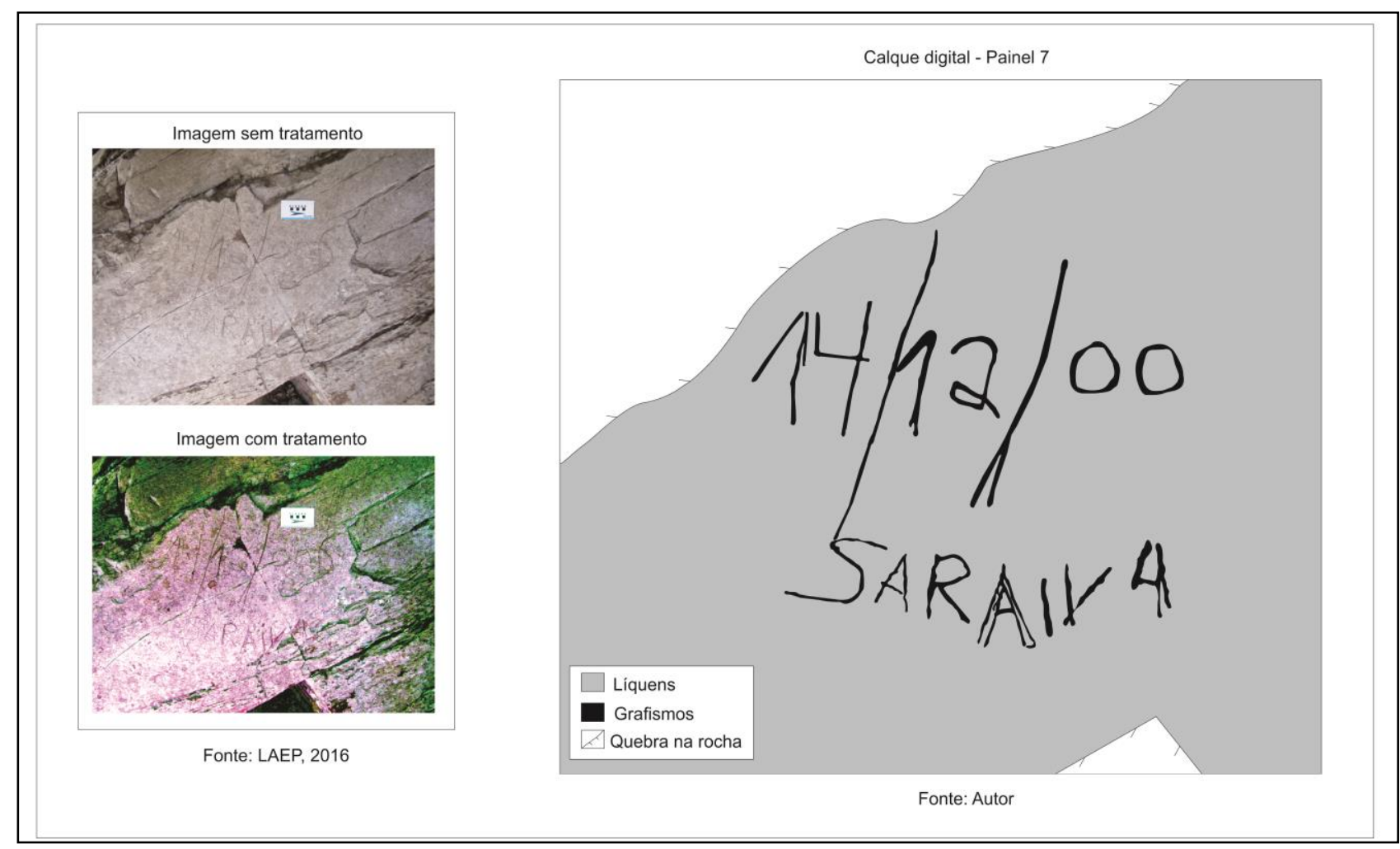

Figura 04 Painel 04 do sítio Sampaio.

Fonte: Greco/2016.

As relações entre os símbolos "S", “A", "R", "A", "I", "V" e “A”, ordenados de modo único, constituem um sentido maior que não se limita a palavra forma. A leitura das relações entre os símbolos possibilita sua interpretação, que está mais próxima da ideia da coisa representada que da representação da coisa. Todavia, a interpretação não tem a ver com o que é visto em si, muito menos com a valorização, que não está no símbolo, mas é criada, transmitida e ensinada em relação a ele. Em campo, facilmente, pode-se interpretar o que está inscrito/escrito no painel 4, mas o conhecimento dos processos de relações entre os símbolos só proporcionou e proporciona a compreensão dos símbolos, nunca do(s) significado(s). Por isso equiparar a arte a uma forma de escrita é limitá-la.

Assim, ainda que o processo de relações entre grafismos que se assemelham a representações de cervídeos, peixes, traços e antropomorfos, fosse conhecido, é possível que seus significados nunca fossem alcançados. Até porque, certamente, eram extremamente dinâmicos, como os lugares, estilos e paisagem, assim como os humanos neles.

s reflexões promovidas no painel 4 corroboram à análise e entendimento de outros painéis identificados: o painel 3, por exemplo. Nele foram identificados alguns casos de sobreposições e justaposições. Em virtude de suas características, considerou-se pertinente discuti-los conjuntamente (Figura 05) 


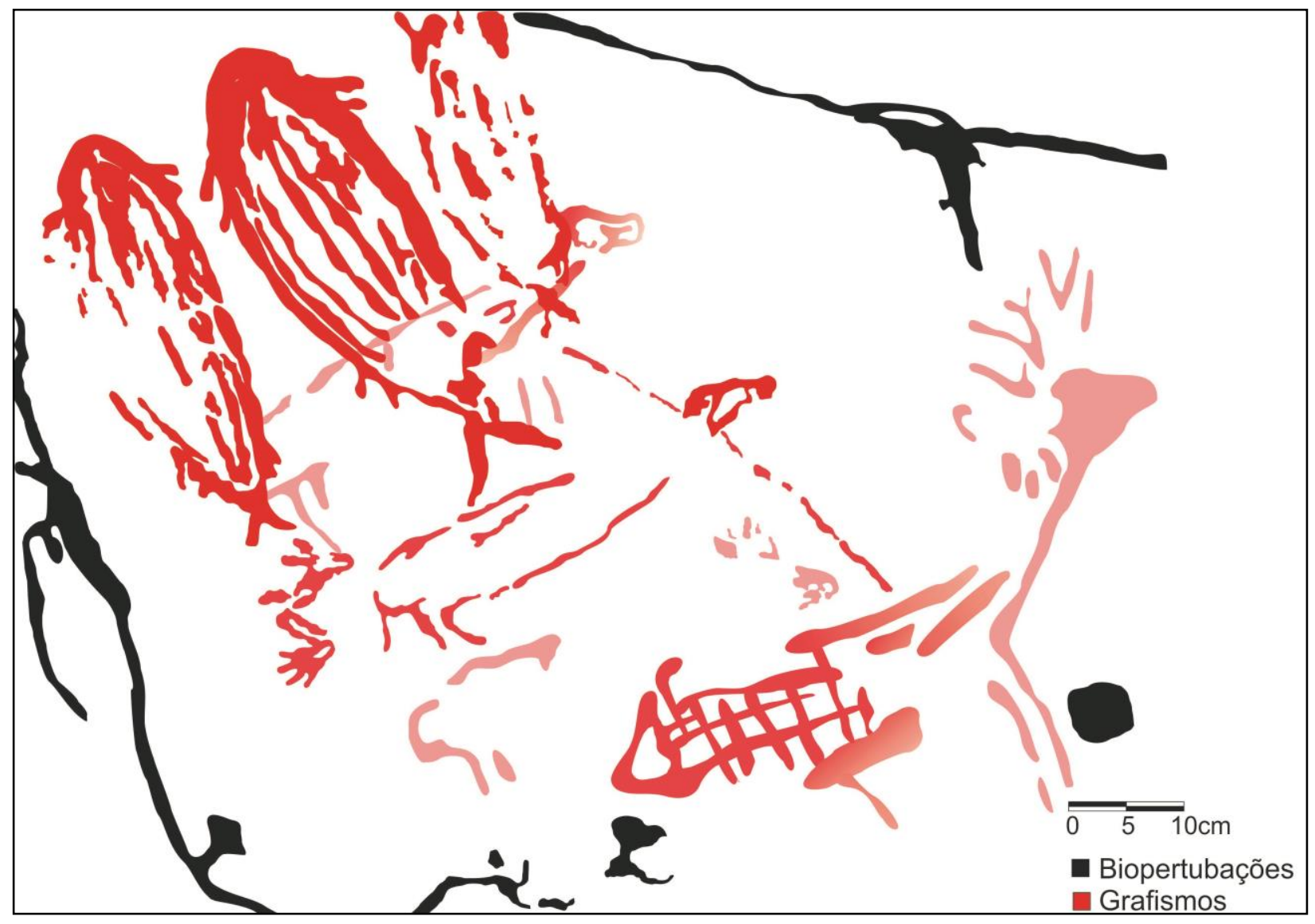

Figura 05 Ocorrências de justaposição e sobreposição no painel 3.

Fonte: Greco/2016.

As pinturas zoomorfas, representações de cervídeos, inauguraram este painel, todas apresentando uma mesma tonalidade de pigmento vermelho, sendo possível que tenham sido pintados em uma pequena diferença de tempo. Contudo, nenhum dos grafismos se sobrepõe a outro, havendo em todas há algum traço que se associa a outra por aproximação. Apesar de o painel não ter grandes dimensões, é perceptível que esse contato, se não foi intencional, ao menos não foi evitado. De qualquer modo, isso evidencia uma possível associação entre os termos. Em uma tonalidade muito parecida ao dessas pinturas, existe um traço que 'corta' todo o painel transversalmente. Desse modo, ele se associa a três dos zoomorfos e faz menção à "barbatana" de um dos peixes pintada em sua direção.

Os grafismos em forma de peixes foram os últimos a serem pintados. Também em vermelho, possuem uma tonalidade de tinta muito mais forte (viva), que os cervídeos que os precederam. Eles se encontram em associação de sobreposição e justaposição direta a somente um dos cervídeos, que tem o corpo todo sobreposto, exceto a cabeça. Foram pintados em uma mesma sequência e, aparentemente, sob um mesmo critério de sobreposição ao cervídeo, em que somente a parte do corpo próxima à cauda que se sobrepõem, de modo que o desenho da cauda, propriamente, fica abaixo da linha de contorno do corpo do "mamífero". A cabeça de um dos cervídeos possui a 
mesma cor que os peixes, sendo possível que ela tenha sido repintada por aquelas que os desenharam, já que as condições de preservação parecem ter sido a mesma em toda a figura.

Isso corrobora ainda mais à hipótese de associação e reafirmação entre os diferentes grafismos durante os momentos de ocupação do painel. Não obstante, ainda assim, pouco se pode afirmar com segurança a respeito de quais teriam sido essas relações, por quais agentes e em quais momentos. Talvez essas sejam perguntas que nunca serão respondidas, ao menos por agora.

Em campo, pode-se observar uma característica em um dos peixes que se considera relevante. Associado aos traços que formam a cabeça do cervídeo, ele é menor que os outros. Tendo em consideração que os outros dois peixes possuem dimensões próximas, essa diferença pode ter se dado devido à relação de sobreposição e justaposição. Se esse desenho fosse maior, certamente, se feito no mesmo lugar, ficaria sobreposto a outro peixe e/ou à cabeça do cervídeo, algo que, em todos os casos, pareceu ser evitado. Contudo, em contrapartida, poder-se-ia argumentar que o desenho foi feito assim pelo fato de que tal representação deveria ser feita desse modo, sob essas dimensões e relações entre os outros grafismos (que são termos e signo). Ou, ainda, também seria possível sustentar que a razão de suas formas, simplesmente, se justifica na vontade e liberdade de escolha de quem o fez.

Apesar de ser impossível comprovar qualquer uma dessas hipóteses, acreditamos que todas são possíveis, inclusive a que atribui à vontade do pintor as formas de seus desenhos. Dizer que algo foi feito segundo a vontade de alguém, mesmo que parece simples e inútil, é um argumento extremamente complexo e válido à pesquisa.

Os desejos, percepções e necessidades da humanidade, ambos são orientados e limitados por seu universo cultural. O modo de perceber, interpretar e sentir o mundo, as ordens moral e valorativa, os diversos comportamentos e posturas corporais, as ações sociais, econômicas e políticas, são produtos de uma herança cultural, que só têm, fazem e precisam ter sentido dentro do próprio contexto cultural, de seu universo sob específica lógica e ordem, como se fossem o resultado mais bem-acabado de sua operação sistêmica.

\section{CONSIDERAÇÕES FINAIS}

Em síntese, a paisagem é plurimodal, imagem e representação (BERQUE, 1984). Nesse sentido, o seu estudo é imprescindível à pesquisa arqueológica, com vista à compreensão do comportamento humano (FAGUNDES, 2014).

As pinturas são registros de ação, vestígios de arte, justamente por isso partiu-se da análise dos grafismos, não considerando a arte rupestre apenas como objeto de estudo, mas como estratégia de observação do comportamento humano, objeto de maior interesse em Arqueologia. 
O modo de organização dos signos nos painéis rupestres revela como esses processos de relação e interação humanidade/ambiente se deram. As pinturas fizeram de Sampaio um lugar (TUAN, 1983), que foi marcado, lembrado, caracterizado e consagrado (aos humanos ou aos seus mitos, ao que se vê ou ao que se sente). Um todo coeso e coerente que tira das relações entre os seus termos o sentido de sua existência.

Ainda hoje, o sítio Sampaio está e faz parte da dinâmica do presente e se relaciona intrinsecamente com a população atual que habita o meio ao seu entorno imediato. As intervenções recentes em uma de suas paredes, os sentimentos de identificação com ele, a condição de preservação e o interesse de sua análise caracterizam como um mesmo lugar pode ser percebido e caracterizado de modos diferentes, não existindo em sentido único, mesmo sento vetor de toda significação.

A arte rupestre de Sampaio apresenta de modo particular motivos conhecidos e identificados em outros sítios. Os zoomorfos, antropomorfos e geométricos se associam de maneira intrínseca, em interações entre espaços vazios e preenchidos, onde os sentidos se constroem como que por uma teia de conexões entre os termos. Nos diferentes painéis, os antropomorfos se apresentam de modo distinto. No painel 1 todos são filiformes simples (Figura 06). Já no painel 2, eles possuem o contorno que, possivelmente, correspondem a cabeça, dedos das mãos e pés.

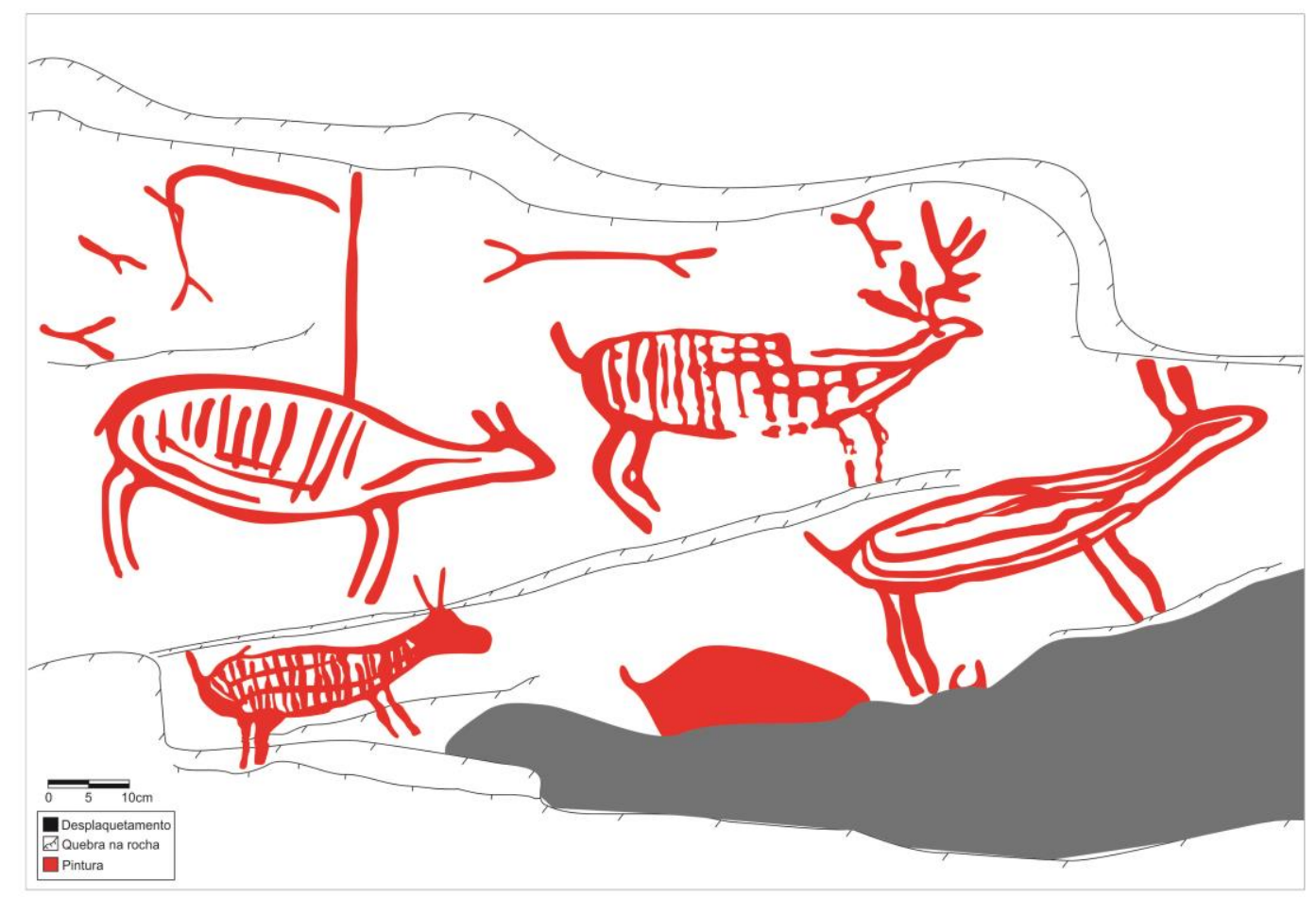

Figura 06 O painel 1 de Sampaio

Fonte: GRECO, 2017.

Os peixes foram identificados apenas no painel 2 e 3. No painel 2 eles possuem características muito semelhantes e distantes dos observados no do teto do abrigo, painel 3. 
Contudo, em ambos os painéis em que se encontram, estão voltados em uma mesma direção, assim como os cervídeos, com exceção de três casos (os dois na vertical e o único em amarelo). Essa particularidade é interesse, uma vez que revela uma técnica de produção dos grafismos que parece ser comum a cada categoria. Elas guardam uma compatibilidade, uma coerência que pode ter sido a razão da interpretação do sentido(s), como ressalta Andrés Troncoso (2002).

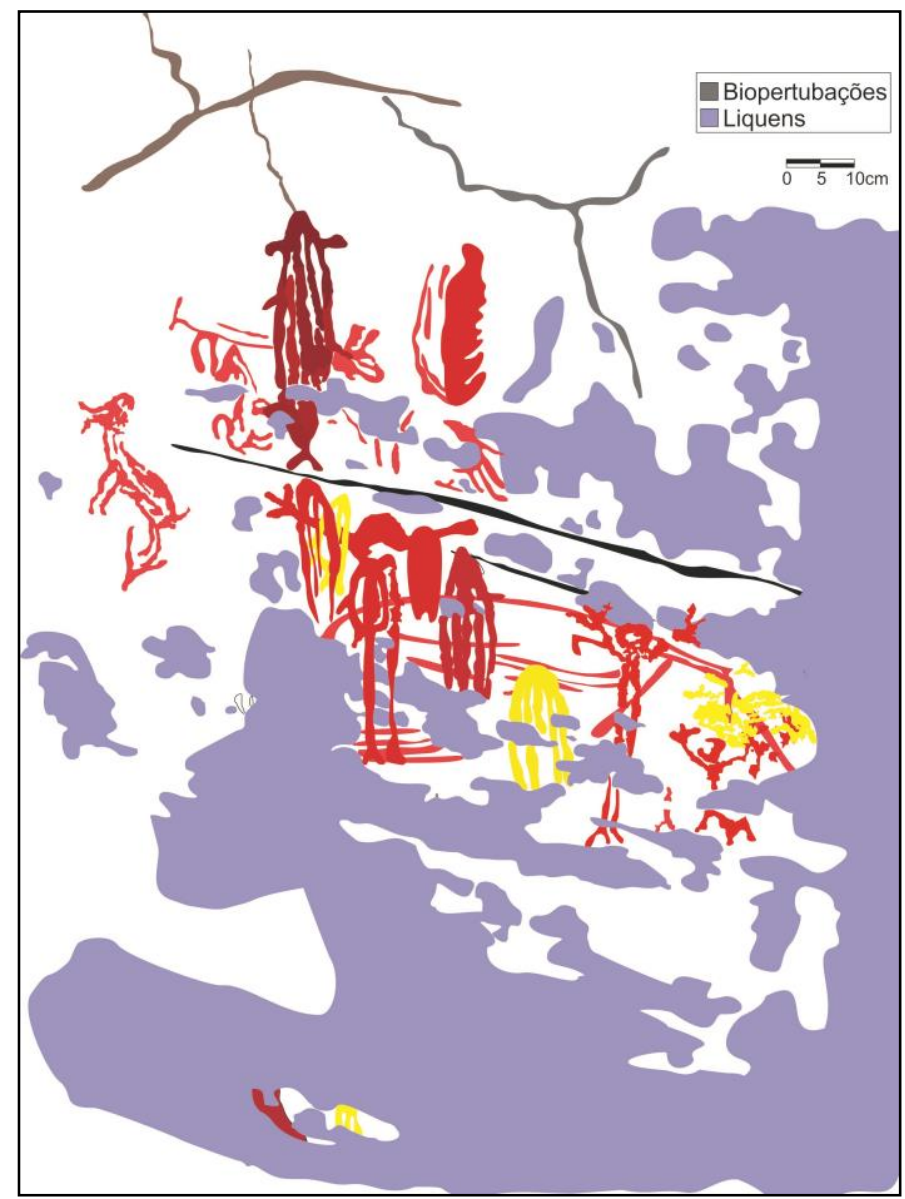

Figura 0710 painel 2 de Sampaio. Fonte: GRECO, 2017.

Em relação aos zoomorfos, todos possuem um traço distinto para o contorno do corpo, que não se confunde com o preenchimento, constituído por traços dispostos de modo ordenado, em paralelas ou perpendiculares. Apesar de todos se assemelharem a representações de cervídeos, são muito diferentes em suas características.

Cabe ressaltar que os símbolos não são os mesmos, por isso buscar entendê-los sob categorias e conceitos generalizados, de modo generalizador, seria um equívoco. As categorias 'antropomorfo' e 'zoomorfo', por exemplo, são elaborações atuais que não devem limitar e direcionar o estudo em arte rupestre. Por isso, como tantos outros conceitos que permearam o estudo em arte rupestre, considera-se que a utilização de cada um deles de modo crítico, onde as particularidades de cada figura não fiquem sufocadas por eles. 
A razão das características das figuras reside em suas particularidades e em suas relações com os demais termos existentes no painel, incluindo a superfície rochosa. É no modo de constituição dos painéis, ou seja, na maneira de organização das pinturas sobre a rocha, que se encontram os discursos que orientaram as escolhas que os construíram e deles se valeram.

Assim, estando intimamente relacionada ao seu contexto, a arte só tem função e significação específicas sob uma determinada lógica, e tão somente. Contudo, o seu significado não está nos grafismos, ele é de relação, está entre eles e os humanos envolvidos em uma sensibilidade que os permitem e permitiram percebê-los.

Infelizmente, não se pode identificar com clareza se todas as paredes do abrigo foram grafadas ou, com isso, observar possíveis critérios de escolha das superfícies rochosas a serem pintadas. Apesar disso, todos os painéis são visíveis e de fácil acesso, o que possibilita afirmar que, se não era uma intenção clara, sua exposição também não foi uma preocupação.

Em Sampaio foi possível identificar duas técnicas de execução dos grafismos, a pintura e o crayon, além do picoteamento (se consideradas as intervenções recentes). Modos de associações entre as temáticas, identificados em outros sítios, também puderam ser percebidos, como a relação entre cervídeo e antropomorfos, cervídeos e peixes. Já a associação entre antropomorfo e peixes ainda não foi verificada em outros sítios da região.

No que tange a relação de Sampaio com os outros sítios próximos, além das ocorrências de sobreposição e justaposição, o sítio se particulariza pela diversidade nas formas das temáticas, em especial dos antropomorfos, únicos entre os sítios conhecidos.

Outra característica relevante é o modo de composição dos zoomorfos, onde, em todos, o contorno não se mistura ao preenchimento. A execução das pinturas em poucos traços e contínuos também ressalta a perfeição técnica e experiência de seus agentes.

Consideramos válido que o modo de organização dos signos nos painéis rupestres revela como esses processos de relação e interação humanidade/ambiente se deram. As pinturas fizeram de Sampaio um lugar, um lugar de sentido que foi marcado, lembrado, caracterizado e consagrado (aos humanos ou aos seus mitos, ao que se vê ou ao que se sente). Um todo coeso e coerente que tira das relações entre os seus termos o sentido de sua existência.

\section{REFERÊNCIAS}

ALVES, I. M. F. A singularidade do lugar: em The Turquoise Ledge de Leslie Marmon Silko, RUA-L. Revista da Universidade de Aveiro, n. ${ }^{\circ} 2$ (II. série), p. 153-166, 2013/14.

ANCHUETZ, K.F; WILSHUSEN, R. H./ SCHEICK, C. An Archaeology of Landscapes: Perspectives and Directions. Journal of Archaeological Research, 09 (02), pp. 157-211, 2001 
BERQUE, A. Paysage-empreinte, paysage-matrice: éléments de problématique pour une géographie culturelle. Espace géographique, v. 13, n 1, p. 33-34, 1984.

BERQUE, A. Milieu, trajet de paysage et déterminisme géographique. Espace géographique, tome 14, n², p. 99-104, 1985.

CLAVAL, P. A geografia cultural. Tradução de PIMENTA, L. F.; PIMENTA, M. C. A. $3^{\text {a }}$ ed. Florianópolis: Editora da UFSC, 2007.

COLLOT, M. Pontos de vista sobre a percepção das paisagens. Tradução de Denise Grimm. Literatura e Paisagem em diálogo. Rio de Janeiro: Edições Makunaima, p. 11-29, 2012.

COSGROVE, D. A geografia está em toda parte: cultura e simbolismo nas paisagens humanas. In: CORRÊA, R. L.; ROSENDAHL, Z. (orgs) Paisagem, Tempo e Cultura. Rio de Janeiro: EDUERJ, 1998.

COSGROVE, D. Towards a Radical Cultural Geography of Theory. Tradução de SILVA, O. B. L. Espaço e Cultura, n. 5, p.5-29, 1998..

FAGUNDES, M. Natureza e Cultura: estudo teórico sobre o uso conceito de Paisagem nas Ciências Humanas. Revista Tarairiú. Campina Grande-PB, Ano V, v. 1, n. 7, p. 32-54, 2014.

FAGUNDES, M. Arqueologia e paisagens das terras altas mineiras: Serra do Espinhaço Meridional. MORRODOPILAR carta arqueológica, p. 38-71, 2015.

GEERTZ, C. O saber local: novos ensaios em antropologia interpretativa. Tradução de Vera Mello Joscelyne. Petrópolis: Vozes, 1998.

GUEDES, C. M. A semântica dos signos na arte rupestre: estruturas da cognição. São Paulo: Programa de pós-graduação do Museu de Arqueologia e Etnologia (MAE), Universidade de São Paulo (USP), Tese de Doutoramento, 2014. 374f. Disponível em: <http://www.teses.usp.br> Acesso em: setembro de 2016.

INGOLD, T. The temporality of the landscape. World Archaeology, v. 25, n. 2, p. 152-174, 1993.

INGOLD, T. The Perception of the environment: Essays on livelihood, dwelling and skill. London: Routledge, 2002.

KNAPP, A.B; ASHMORE, W. Archaeological landscapes: constructed, conceptualized, ideational. Archaeologies of landscape: contemporary perspectives. University of Arizona, pp. 1-30, 1999.

LE GOFF, J. Documento/Monumento. In: História e memória; tradução Bernardo Leitãoet al.. Campinas: Editora da UNICAMP, 1990.

LEROI-GOURHAN, André. EL gesto y la palabra. Técnica e linguagem. Tradução de Felipe Carrera. Caracas: Universidad Central de Venezuela, 1971.

LÉVI-STRAUSS, C. Tristes Trópicos. Tradução de Wilson Martins. São Paulo: Editora Anhembi Ltda, 1957.

LÉVI-STRAUSS, C. O Olhar Distanciado. Tradução de Carmen de Carvalho. Lisboa: Edições 70, 1983. 
LÉVI-STRAUSS, C. A Oleira Ciumenta. Tradução de Beatriz Perrone-Moisés. São Paulo: Editora Brasiliense S.A., 1985.

LÉVI-STRAUSS, C. O Pensamento Selvagem. Tradução de Tânia Pellegrini. Campinas: Papirus, 1989.

MARIA, Y. L. Paisagem: entre o sensível e o factual - Uma abordagem a partir da Geografia Cultural. 2010. 133f. Dissertação de Mestrado. Programa de Pós-Graduação em Geografia Humana, Departamento de Geografia, Faculdade e Filosofia, Letras e Ciências Humanas, Universidade de São Paulo, São Paulo, 2010.

MAUSS, M. Sociologia y Antropologia. $4^{\mathrm{a}}$ ed. Traduzido por MARTIN-RETORTILLO, T. R. Madrid: Editorial Tecnos, S. A., 1979.

MEINIG, D. W. O olho que observa: dez versões da mesma cena. Espaço e Cultura, n. 13, p. 3546, 2002.

OLIVEIRA, L. D. A arte rupestre como signo: uma abordagem semiótica do fenômeno infocomunicacional. Congresso Internacional da IFRAO - Piauí, p. 296-312, 2009.

RODRIGUES, J. C.O tabu do corpo, 2ª ed. Rio de Janeiro: Achiamé, 1975.

SANTOS, M. P. A Paisagem como Imagem e Representação do Espaço na Geografia Humana. GEOUSP - Espaço e Tempo, n. 28, p. 151-165, 2010.

SERPA, A. Paisagem, lugar e região: perspectivas teórico-metodológicas para uma geografia humana dos espaços vividos. GEOUSP - espaço e tempo, São Paulo, n. 33, p. 168- 185, 2013.

SOUZA, J. A tolice da inteligência brasileira: ou como o país se deixa manipular pela elite. São Paulo: LeYa, 2015

TROnCOSO, A. M. Espacio y Poder. Boletín de la Sociedad Chilena de Arqueología, n. 32, p.10-23, 2001.

TRONCOSO, A. M. A propósito del arte rupestre. Werken, n. 3, Santiago de Chile, Universidad Internacional SEK, p. 67-79, 2002.

TUAN, YI-FU. Espaço e lugar: a perspectiva da experiência. Tradução de Lívia de Oliveira. São Paulo: DIFEL, 1983.

VIVEIROS DE CASTRO, E. A inconstância da alma selvagem e outros ensaios de antropologia. $2^{a}$ ed. São Paulo: Cosac Naify, 2006.

ZVELEBIL, Marek. Hunter-gatherer ritual landscapes: spatial organization, social structure and ideology among hunter-gatherers of northern Europe and western Siberia. Analeca Praehistorica Leudesia, 29, pp. 33-50, 1997. 